\title{
The Endogeneity Of Association Agreements And Their Impact On Trade For Eastern Countries: Empirical Evidence For Romania
}

Christophe Rault, (Email: chrault@hotmail.com), University Of Orleans And IZA, France

Ana Maria Sova, (Email: anamariasova@yahoo.fr), Sorbonne University, France And A.S.E, Romania

Robert Sova, (Email: anamariasova@yahoo.fr), Sorbonne University, France And A.S.E, Romania

\begin{abstract}
The main goal of regionalization is the creation of free trade areas and the guarantee for countries to accede to a widened market. Many studies dealing with the effects of regional free trade agreements on trade flows already exist in economic literature and the increase of regional agreements among nations has recently stressed the key role of regionalization. However, the effects of agreements on trade have not yet been clearly determined in those studies. Our research in this paper aims at reassessing the genuine role of associations. For this matter, we particularly study the association of Romania with European Union countries. Our econometric analysis based on qualitative choice models highlights in particular why European countries chose to conclude an association agreement with Romania, and stresses the fact that European Union countries select endogenously the conclusion of association agreements. We also find a 29\% positive impact of the association agreement on Romanian export performances.
\end{abstract}

Key Words: Regionalization, European integration, Qualitative choice models, Probit

\section{Introduction}

lobalization has already been the subject of various debates. It is now the norm in literature to distinguish between two main streams: the former considers that a world with trade freedom is better than a world with tariff and non-tariff barriers. The latter suggests that some specific but limited tariff and non-tariff barriers are preferable to a complete trade freedom. Actually, since the end of World War II it seems that trade liberalization has developed more on a local scale than on a global one, and has led to the development of various free trade areas (for example, the European Economic Community, or the Free Trade European Association).

Since the 1960s Western Europe has been "the most interesting and successful regional liberalization process" $"$. The 1990 s was the most appropriate period for a deeper economic integration.

Many studies dealing with the effects of regional free trade agreements on trade flows already exist in the economic literature; the explosion of regional agreements among nations has recently stressed the key role of regionalization. However, the effects of agreements on trade have not yet been clearly determined in them. Our research in this paper aims at reassessing the genuine role of associations. For this matter, we first theoretically study the association of Romania with European Union countries (EU). Our econometric analysis based on qualitative choice models highlights why European countries have chosen to conclude an association agreement

1 Ana Paula Silva (2001) «EU Enlargement and Trade Adjustments ». 
with Romania, and stresses the fact that European Union countries have selected endogenously the conclusion of association agreements. In this perspective we proceed as follows: we first try to find the main determinants that better characterize the European agreement using qualitative models (probit). We then calculate the marginal effects that provide indications of the quantitative contribution of each determinant to the probability to conclude association agreements between countries. And finally, we try to determine the effects of association agreements on trade exchanges. We are particularly interested in the two following issues: (i) do European agreements have a main goal to increase the trade exchanges of their members and (ii) if so, how much?

The remainder of the paper is organized as follows. In Section 2 we address the European agreements, and we briefly review their main determinants in Section 3. In Sections 4 and 5 we report our empirical investigation as well as our econometric results and discuss their policy implications. Finally we summarize the paper's major findings in Section 6.

\section{European Agreements}

Since the nineties, Western Europe has had to face the economic and political changes of Eastern Europe. The main concern of Western Europe has been the creation of a framework aiming at facilitating and strengthening the gradual economic and political integration with Central and Eastern Europe. The solution retained has been to propose a former European policy: Preferential trade relationships were established as «European Agreements», or «Association agreements» in the early nineties.

All candidate countries signed Association agreements with the European Union (EU), establishing the creation of a free trade area, dialogue modalities between governments and community institutions. These agreements were signed ${ }^{2}$ on a bilateral basis : having a political and economic motivation. The impact of regional blocks on trade flows has already been the subject of important literature.

Some of the econometric results reported in these studies were contradictory, even concerning the European Community (EC). For instance, researchers like Aitken (1973), or Abrams (1980) found that the EC had a significant impact on the trade exchanges of community members. On the contrary, Bergstrand (1985) found an insignificant effect. Besides, Frankel (1997) found a significant but negative effect of the agreement impact for EC members, because intra-European trade can be explained by "various natural factors with little role of EC until 1980". These diverging results can be explained by the potential endogeneity bias of the agreement variable. Ghosh and Yamarik (2004) tried to test the robustness of the regional agreement variable effect by using cross section data. They suggest that its effect may be over- or under-estimated due of the potential endogeneity of this variable. Besides, they stressed that countries select endogenously the conclusion of regional agreements according to determinants which sometimes are not all observable and measurable by econometricians. These findings are confirmed by Baier and Bergstrand (2005) who point out that the regional agreement variable is not exogenous and the estimation of a gravity model using cross section data for investigating the quantitative effect of this variable on trade flows may be biased due to unobservable heterogeneity and/or omitted variables.

We now try in the next section to identify more precisely the main determinants that characterize better European agreements.

\section{The Main Determinants Of Association Agreements}

The analysis of the effect of regional integration agreements was considerably enriched not only with mechanisms involving scale economies (the location of firms) but also with the non-economic gains of regional integration. Non-economic objectives are also reasons for the conclusion of regional agreements. Political stability

\footnotetext{
${ }^{2}$ Hungary (1991), Poland (1991), Romania (1993), The Czech Republic (1993), Slovakia (1993), Bulgaria (1993), Latvia (1995), Estonia (1995), Lithuania (1995), Slovenia (1995).
} 
in the agreement zone, intensification of democracy, guarantee of policy irreversibility, higher security, and power of negotiation increased with third parties, and are all variables which may explain the agreement conclusion.

De Melo et al. (1993) showed that regional agreements allow implementing the most effective policies within the passage of the national framework to the regional framework, since the reduced power of lobbies. Integration agreements obligate political decision-makers to implement the institutions of countries (which are already members) and to cede to the former. Moreover, decision making at a regional level takes better into account the needs of the various countries.

The irreversibility of economic policies is guaranteed because trade agreements do not allow governments to implement a discretionary policy or to implement again a protectionist trade policy ${ }^{3}$. Then, agreements make domestic reforms of economic policies irreversible.

Regional agreements have increasing effects on the negotiation power of members with third countries and permit faster trade liberalization than within the multilateral framework.

Concerning "the security capital" of a country, it symbolizes confidence in the neighboring country. Indeed, according to Schiff and Winters (1998), the security capital of a country represents the consumers' utility function and positively depends on imports from the nearby country. Consequently, the higher imports are, the higher confidence is in the nearby country.

Free trade agreements are not exogenous. Baier and Bergstrand (2005) noticed that very few theoretical and empirical works exist examining the determinants of the conclusion of agreements. Moreover, they developed a theoretical and econometric specification to put in evidence the endogeneity of regional agreements using economic and political instruments. Pairs of countries that signed an agreement tend to share common economic characteristics associated with important trade and with a net trade creation that determines welfare growth. Regional agreements, like every regional policy, are actually an endogenous potential variable. The bias resulting from not considering this variable as endogenous is an important question that was neglected in literature. According to the authors this endogeneity bias can be the consequence of omitted variables that can be connected to the Regional Agreement variable.

Krugman (1991) showed that countries that try to conclude an agreement are natural commercial partners and are close from a geographic point of view.

Mansfield, Milner and Rosendorff (2002) introduced a theoretical and econometric model showing that due to the conclusion of an agreement, a government becomes more democratic and its leaders have higher profits through trade liberalization.

There exist different sets of factors determining the decision of the two governments to conclude an agreement. For instance, Baier and Bergstrand (2005) mentioned the importance of political variables and pointed out that a regional agreement is more likely to emerge when governments are more democratic.

Having now reviewed economic and non economic gains, and given that the regional agreement variable is not exogenous, we propose in the next section to estimate an econometric model that highlights the determinants of a regional agreement concluded between countries with a different development level. We are particularly interested in identifying the main reasons for the conclusion of an association agreement between the Romanian government and EU countries.

3 Fernandez and Portes (1998). 


\section{Econometric Investigation}

The agreement can be modeled by a parametric form using a model of qualitative choice. The data spans an 18 year period (from 1987 to 2004), and covers a sample of 19 OECD countries ${ }^{4}$ organized in a panel framework (country, partner, year).

Our binary qualitative model shows that Romania's decision of economic and political integration into EU is influenced by two categories of economic and non economic variables.

The PROBIT model permits taking the decision-making process into account and examining the contribution of the various determinants to this process.

From economic and political conditions we found five convenient explanatory variables that best characterize the association process to EU. These variables are:

- the difference between the GDP per capita of the partner countries $\left(\operatorname{DGDP}_{\mathrm{ijt}}\right)$, reflecting a relative factor endowment in terms of GDP per capita $\left(\mathrm{GDP}_{\mathrm{i}, \mathrm{j}} / \mathrm{POP}_{\mathrm{i}, \mathrm{j}}\right.$ ) (source : CHELEM, CEPII Data Base);

- $\quad$ the geographic distance between the capitals of partner countries (Dist $\mathrm{ij}_{\mathrm{ij}}$ ),

- $\quad$ reflecting a proxy for transport costs (source : CEPII Data Base);

- $\quad$ the traditional trade relations between countries $\left(\operatorname{Reltrad}_{\mathrm{ij}}\right)$,

- $\quad$ (author's calculus using data from CHELEM, CEPII Data Base);

- $\quad$ the political stability of countries $\left(\right.$ Stabpol $\left._{\mathrm{i}}\right)$, (source : Freedom House);

- $\quad$ Foreign direct investments $\left(\operatorname{Inv}_{\mathrm{ijt}}\right.$ ), (source: OECD Database).

The econometric specification used is the following:

$$
A c c_{i j t}=a_{0}+a_{1} \log \left(D_{\text {GDP }}{ }_{\mathrm{ijt}}\right)+\mathrm{a}_{2} \log \left(\text { Dist }_{\mathrm{ij}}\right)+\mathrm{a}_{3} \operatorname{Reltrad}_{\mathrm{ij}}+\mathrm{a}_{4} \operatorname{Stabpol}_{\mathrm{it}}+\mathrm{a}_{5} \log \left(\operatorname{Inv}_{\mathrm{ijt}}\right)+\varepsilon_{\mathrm{ijt}}
$$

, where $\mathrm{Acc}_{\mathrm{ijt}}$ denotes the association agreement between Romania and EU countries (endogenous variable), $\boldsymbol{\varepsilon}_{\mathrm{ijt}}$ is the error term which is assumed to be normally distributed with zero mean and constant variance for all observations.

We first determine the qualitative influence of the explanatory variables (cf. Table 1, column 1) and then calculate the marginal effects (cf. column 2).

The numerical value of the estimated parameters reported in Table 1, column 1 is not directly interpretable. The only really useful information is the sign of parameters that indicates whether the associated variable positively or negatively influences the dependent variable.

The results of the estimation of the association agreement indicate that some of the variable coefficients are positive and others negative.

The lack of similarity of the economies indicates that the variable of economic distance (DGDP $\mathrm{ijt}_{\mathrm{jt}}$ ) has a negative impact on the decision of association agreement. The more the economic distance of countries lowers, the more the countries tend to conclude an agreement. For this variable the coefficient sign is negative.

Traditional trade relationships $\left(\operatorname{Reltrad}_{\mathrm{ij}}\right.$ ) have the role to stimulate partners' interest for the association. Geographic distance (Dist $t_{\mathrm{ij}}$ ) is generally an obstacle in the decision of association, as it is also confirmed by the negative sign in the above estimation. The closer the countries are, the higher the probability for an association agreement.

4 France, Belgium and Luxemburg, Germany, Italy, Holland, England, Denmark, Finland, Sweden, Austria, Spain, Greece, Portugal, Ireland, Switzerland, Canada, Japan, Australia, the United States of America. 
To calculate marginal effects we proceed to another estimation in which variable coefficients indicate the contribution of the different variables in the decision of association agreement. Our results are reported in Table 1, column 2.

Table 1: Estimations of the determinants of the association decision

\begin{tabular}{|c|c|c|}
\hline \multirow[t]{2}{*}{ Variables } & (1) & $(2)$ \\
\hline & Agreement & Agreement \\
\hline \multirow[t]{2}{*}{ DGDP $_{\mathrm{ijt}}$} & -2.091 & -0.744 \\
\hline & $(-2.76) * * *$ & $(-2.74) * * *$ \\
\hline \multirow[t]{2}{*}{ Dist $_{\mathrm{ij}}$} & -2.883 & -1.026 \\
\hline & $(-5.71) * * *$ & $(-5.86)^{* * *}$ \\
\hline \multirow[t]{2}{*}{ Reltrad $_{\mathrm{ij}}$} & 0.481 & 0.165 \\
\hline & $(1.66)^{*}$ & $(1.645)^{*}$ \\
\hline \multirow[t]{2}{*}{ Stabpol $_{\text {it }}$} & 2.947 & 0.814 \\
\hline & $(9.58) * * *$ & $(16.59)^{* * *}$ \\
\hline \multirow[t]{2}{*}{$\operatorname{Inv}_{\mathrm{ijt}}$} & 1.608 & 0.560 \\
\hline & $(5.81) * * *$ & $(6.63) * * *$ \\
\hline \multirow[t]{2}{*}{ Constant } & 16.035 & \\
\hline & $(4.98) * * *$ & \\
\hline No. Observations & 342 & 342 \\
\hline Number of groups & 19 & 19 \\
\hline Correctly classified & $86.75 \%$ & \\
\hline ROC curve & 0.9241 & \\
\hline \multicolumn{3}{|c|}{ Absolute value of $\mathrm{z}$ statistics in parentheses } \\
\hline \multicolumn{3}{|c|}{$*$ significant at $10 \% ; * *$ significant at $5 \% ; * * *$ significant at $1 \%$} \\
\hline
\end{tabular}

These results reveal that previous coefficient signs are preserved. We observe that the political stability variable and the foreign direct investment variable influenced more the conclusion of the association, confirming that the main objective of the association was the creation of a stable zone from a political and economic point of view.

The foreign direct investment variable indicates that it was a common interest for both the investor country and the host country, given the potential gains for the two partners.

Concerning the economic distance, it is a resistance factor against the association due to different levels of economic development. The influence of traditional trade relationships is positive as shown before but its contribution is low.

The gains from the signature of the association agreement are those associated with the advantages of the foreign direct investment and political stability.

We now analyze in the next section the impact of the European agreement on exports between countries.

\section{The Impact Of The Association Agreement On The Export Performances}

Our main goal is to determine the effect of the association agreement on Romanian export performances, and to measure its impact. We use the gravity model that permits analyzing the effects of regional agreements on trade flows between two countries ${ }^{5}$. The trade flows of the country $i$ towards the country $j$ is a function of the offer

5 Theoretical foundations of the gravity model are provided by Linnemann (1966), Helpman and Krugman (1985), Bergstrand (1985), Evenett and Keller (2002) etc. 
of the exporter country and of the demand of the importer country and of the resistance of trade between countries. In other words the national incomes of two countries, transport costs (transaction costs) and regional agreements are the basic determinants of the model.

Various specifications of the model have been used by researchers to underline the role of regional blocks on trade exchanges ${ }^{6}$. Concerning the dependent variable, it is approximated in literature either by exports or imports. As for us, we use in our econometric estimation exports to determine the impact of the association agreement on the exports of Romania to EU.

In the first part of our study we showed that regional agreement variables are endogenous. In the second part we try to determine the impact of association agreement on export performances, evidence from Romania. In particular, do European agreements strive to increase the trade exchanges of their members and if so, how much?

Our purpose here is not only to put prove a positive effect of the European association agreement on Romanian exports but also to quantify its influence on the increase of trade exchanges. A panel data approach is suitable because it allows control for individual heterogeneity. Standard cross section estimates of the gravity model lead the contrary to biased results of the bilateral trade volume because they do not permit to control for heterogeneity (see Baltagi, 2003).

Besides, the use of panel data techniques enables to take specific effects (fixed or random effects) into account. The source of the endogeneity bias in the gravity model is unobserved individual heterogeneity. The choice of the retained method (Fixed Effects Model versus Random Effect Model) depends actually on two important things: its economic and econometric relevance ${ }^{7}$. From an economic point of view there exist time invariant, unobservable and difficult to quantify variables. These can simultaneously influence some explanatory variables and trade volume. From an econometric point of view the inclusion of fixed effects is preferable to random effects because the rejection of the null assumption of no correlation of the unobservable characteristics with the agreement variable is less plausible.

We use panel data models with fixed effects (within, year, importer country) to eliminate the heterogeneity coming from unobserved variable correlated with some explanatory variables.

The estimated model is the following:

$\log \left(\mathrm{X}_{\mathrm{ijt}}\right)=\mathrm{a}_{0}+\mathrm{a}_{1} \log \left(\mathrm{GDP}_{\mathrm{it}}\right)+\mathrm{a}_{2} \log \left(\mathrm{GDP}_{\mathrm{jt}}\right)+\mathrm{a}_{3} \log \left(\right.$ DGDP $\left._{\mathrm{ijt}}\right)+\mathrm{a}_{4} \log \left(\right.$ Dist $\left._{\mathrm{ij}}\right)+\mathrm{a}_{5} \mathrm{Acc}_{\mathrm{ijt}}+\mathrm{a}_{6} \log \left(\mathrm{Tchr}_{\mathrm{ijt}}\right)+\mathrm{a}_{7} \mathrm{~d}_{\text {time }}+$ $\mathrm{a}_{8} \mathrm{~d}_{\text {importer }}+\varepsilon_{\mathrm{ijt}}$

where $\mathrm{X}_{\mathrm{ijt}}$ are the exports from country $\boldsymbol{i}$ towards country $\boldsymbol{j}$. The explanatory variables used are the gross domestic product of the two partners GDP ${ }_{i t}, G D P_{j t}$, geographic distance Dist $t_{i j}$, the difference in development level DGDP ${ }_{\mathrm{ijt}}$, real exchange rate $\mathrm{Tchr}_{\mathrm{ijt}}$ and the dichotomous variable agreement $\mathrm{Acc}_{\mathrm{ijt}}$, time dummy $\mathrm{d}_{\text {time }}$, partner dummy $\mathbf{d}_{\text {importer }}$ and the disturbance term $\varepsilon_{\mathrm{ijt}}$.

The estimation period goes from 1987 to 2004, i.e. 18 years for a sample of 19 developed countries.

Data is organized in panel with three dimensions: exporter, importers, and years. We estimate equation (2) in a logarithmic form to obtain a linear function and get variable elasticities.

We apply different panel data estimation methods like Pooled Ordinary Least Squares (PLS), Fixed effect model (FEM), Random Effect Model (REM) and we compare the different results.

\footnotetext{
${ }^{6}$ See for instance Frankel, Stein and Wei (1995), Baldwin (1994), Bayoumi and Eichengreen ( 1995), Egger and Pfaffermayr (2003),Winters and Soloaga (2001), Cheng and Wall (2005) etc.

${ }^{7}$ Baier and Bergstrand (2005).
} 
The first regression is a classic one and the results are reported in Table 2, column 1.

In the other regressions, we use panel data techniques to control for heterogeneity due to a correlation between explanatory variables and unobserved characteristics in order to avoid getting biased results.

The possible presence of multicolinearity among variables can bias econometric results. In particular, standard errors can be wrongly higher and/or the coefficients of some variables wrongly insignificant. In order to evaluate this risk of multicolinearity we calculate the variance inflation factor (VIF). Literature indicates that a variance inflation factor value higher than 10 reveals the presence a multicolinearity requiring specific corrections (Gujarati, $1995)^{8}$.

The econometric results show that the agreement positively influences exports between countries, and after the elimination of endogeneity using the fixed effects, the coefficient value of the agreement variable is close to 0.29.

The estimation carried out at an aggregated level put in evidence the positive influence of the association agreement variable on the exports of Romania, which is a result in accordance with previous studies ${ }^{9}$ Coefficients are statistically significant and have the expected signs in accordance with the gravity model.

The strength of the estimators obtained is crucial because it allows us to better quantify the impact of the association agreement on the exports of Romania towards EU market. This is one of the reasons why we use a panel data approach which permits to identify time and country specific effects and to isolate them. Our model allows us to take the global propensity to export of a country into account (with the introduction of fixed or random effects). The introduction of temporal fixed effects permits to capture business cycles as well as the possible changes in the opening degree of all countries. The Hausman test $\left(\mathrm{chi}^{2}=30.99\right.$, Prob $\left.>\mathrm{chi}^{2}=0.00\right)$ rejects the random effect model (REM) in favor of the fixed effects model (FEM). The introduction of (within, country and temporal) fixed effects has improved the quality of the estimations, the $\mathrm{R}^{2}$ coefficient (from 0.84 to 0.95 ).

The estimated coefficients of the FEM are different from those obtained with the REM (for instance for GDP, economic distance, or association agreement variables), which can be explained by the existence of a correlation between some explanatory variables and the bilateral specific effect.

Table 2 clearly puts in evidence the decreasing impact of the European agreement variable from 0.48 in the basic model to 0.46 in the model with temporal effects and to 0.29 in the fixed effects model (within) and the pooled least squares with importer fixed effects. For our estimation sample we can observe an insignificant impact of the temporal specific effects. In order to take the "geographic distance" into account, which is invariant over time we also performed an estimate with fixed importer effects. The estimated coefficients are almost identical with those obtained by the estimator which tends to prove the strength of the estimation.

Additionally, the analysis of the agreement variable coefficient indicates a positive and significant impact of this variable on total exports and hence underlines the effects of EU trade policy through the influence of the European agreement on the exports of associated countries.

\footnotetext{
${ }^{8}$ The calculation of this variance inflation factor (reported here) indicates the absence of multicolinearity.

${ }^{9}$ See for instance Buigez and Martinez (1991), Cheng and Wall (2005), Carrère C. (2006), Winters and Soloaga (2001), Baier and Bergstrand (2005), Ghosh-Yamarick (2004).
} 
Table 2: Estimation results

\begin{tabular}{|c|c|c|c|c|c|}
\hline Variables & OLS & Random & Within & $\begin{array}{l}\text { OLS } \\
\text { With } \\
\text { Time } \\
\text { effects }\end{array}$ & $\begin{array}{c}\text { OLS } \\
\text { With } \\
\text { Importer } \\
\text { effects }\end{array}$ \\
\hline & (1) & (2) & (3) & (4) & (5) \\
\hline & xij & $\mathbf{X i j}$ & $\mathrm{xij}$ & $\mathbf{X i j}$ & $\mathbf{x i j}$ \\
\hline \multirow[t]{2}{*}{$\mathrm{GDP}_{\text {it }}$} & 2.131 & 2.876 & 2.645 & 2.211 & 2.645 \\
\hline & $(5.98) * * *$ & $(12.04) * * *$ & $(9.96) * * *$ & $(3.89) * * *$ & $(9.96) * * *$ \\
\hline \multirow[t]{2}{*}{$\mathrm{GDP}_{\mathrm{it}}$} & 1.203 & 1.267 & 2.338 & 1.206 & 2.338 \\
\hline & $(34.21)^{* * *}$ & $(10.07)^{* * *}$ & $(5.53) * * *$ & $(36.72)^{* * *}$ & $(5.53) * * *$ \\
\hline \multirow[t]{2}{*}{ Dist $_{i j}$} & -1.139 & -1.422 & 0.000 & -1.097 & -1.523 \\
\hline & $(19.84) * * *$ & $(-7.29) * * *$ & (.) & $(-19.74) * * *$ & $(-15.30)^{* * * *}$ \\
\hline \multirow[t]{2}{*}{ DGDP $_{\text {ijt }}$} & 0.071 & 0.402 & 0.169 & 0.06 & 0.169 \\
\hline & $(0.60)$ & $(2.48)^{* *}$ & $(0.58)$ & $(0.18)$ & $(0.58)$ \\
\hline \multirow[t]{2}{*}{$\mathrm{Tchr}_{\mathrm{ijt}}$} & -0.133 & -0.096 & -0.091 & -0.222 & -0.091 \\
\hline & $(-4.82)^{* * * *}$ & $(-3.14)^{* * *}$ & $(-2.78)^{* * *}$ & $(-7.35)^{* * *}$ & $(-2.78)^{* * * *}$ \\
\hline \multirow[t]{2}{*}{$\mathrm{Acc}_{\mathrm{ijt}}$} & 0.478 & 0.318 & 0.290 & 0.459 & 0.290 \\
\hline & $(12.88)^{* * *}$ & $(10.26)^{* * *}$ & $(9.23)^{* * *}$ & $(9.40) * * *$ & $(9.23) * * *$ \\
\hline $\mathrm{d}_{\text {time }}{ }^{(\mathrm{a}}$ & & & & $* * * *$ & \\
\hline $\mathrm{d}_{\text {importer }}{ }^{(\mathrm{b}}$ & & & & & $* * * *$ \\
\hline \multirow[t]{2}{*}{ Constant } & -12.552 & -17.027 & -24.271 & -12.82 & -18.73 \\
\hline & $(-6.27)^{* * *}$ & $(-10.59) * * *$ & $(-14.39) * * *$ & $(-4.24) * * *$ & $(-12.65)^{* * *}$ \\
\hline No. Observations & 342 & 342 & 342 & 342 & 342 \\
\hline Number of groups & - & 19 & 19 & - & - \\
\hline R-squared & 0.84 & 0.80 & 0.76 & 0.87 & 0.95 \\
\hline $\mathrm{VIF}^{10}$ & 1.38 & - & - & 1.75 & 3.86 \\
\hline $\begin{array}{l}\text { Ramsey RESET }{ }^{11} \\
\text { Prob>F }\end{array}$ & $\begin{array}{c}2.66 \\
(0.05)\end{array}$ & - & - & $\begin{array}{c}3.99 \\
(0.03)\end{array}$ & $\begin{array}{c}4.59 \\
(0.00)\end{array}$ \\
\hline $\begin{array}{l}\text { Breusch - Pagan / Cook } \\
- \text { Weisberg }{ }^{12} \text { (before } \\
\text { correction) } \\
\text { Prob>chi2 }\end{array}$ & $\begin{array}{c}9.80 \\
(0.00)\end{array}$ & - & - & $\begin{array}{l}12.77 \\
(0.00)\end{array}$ & $\begin{array}{l}22.41 \\
(0.00)\end{array}$ \\
\hline Hausman ${ }^{13}$ Prob $>$ chi 2 & - & - & $\begin{array}{l}30.99 \\
(0.00)\end{array}$ & - & - \\
\hline \multicolumn{6}{|c|}{ Absolute value of $\mathrm{z}$ statistics in parentheses } \\
\hline \multicolumn{6}{|c|}{$*$ significant at $10 \% ; * *$ significant at $5 \% ; * * *$ significant at $1 \%$} \\
\hline \multicolumn{6}{|c|}{ a) time dummy $;{ }^{\text {b) }}$ importer country dummy } \\
\hline
\end{tabular}

\section{CONCLUSION}

Our study has underlined that European agreements are not exogenous and that in addition to economic motivations there also exist non-economic reasons to conclude a regional agreement. The EU enlargement to Central and Eastern countries is an unprecedented event that has provoked ample discussions. Concerning Romania, their

10 - VIF test for multicolinearity calculates the variance inflation factors for the independent variables specified in the fitted model.

${ }^{11}$ Ramsey Reset test can be used to test for a multitude of specification problems including omitted variables Wooldrege (2002) This test amounts to testing $y=x b+z t+u$ and then testing $t=0$. If no option is specified, powers of the fitted values are $u$ sed for $z$ and otherwise powers of the individual elements of $\mathrm{x}$ are used.

${ }^{12}$ Breusch Pagan/Cook Weisberg test for heteroskedasticity performs a score (Lagrange multiplier) test for $\mathrm{H}$ : $\mathrm{b}=0$ against multiplicative heteroskedasticity; $\operatorname{var}(\mathrm{y})=\mathrm{s}^{2} \exp (\mathrm{b} 1 \mathrm{z} 1+\mathrm{b} 2 \mathrm{z} 2+\ldots+\mathrm{bkzk})$.

${ }^{13}$ Hausman (1978) proposed a test based on the difference between the random effects and fixed effects estimates. Since a fixed effect model (FE) is consistent when ci and xit are correlated, but a random effect one (RE) is inconsistent, a statistically significant difference is interpreted as evidence against the random effects assumption. 
first step toward European integration was the signature of the association agreement ${ }^{14}$. In fact, association agreements legitimated the intention of candidate countries to become members of EU, which was confirmed after the application of these agreements, when these countries individually applied for joining EU.

In our applied modeling we used two categories of variables, economic and non-economic ones. Our econometric results using Romania data indicate that the association agreement was based on traditional trade relationships, on foreign direct investments, on the creation of a political stability and on the tendency of reduction of the economic distance between Romania and EU. In other words an economic convergence of Romania to European countries is an important desideratum for a successful European integration process. The higher the income level of partner countries is, the more countries tend to share economic characteristics, which increases their economic welfare.

The foreign direct investments have strongly influenced the association decision as expected in the literature dealing with the gains for the investor and host countries. Moreover, the fact that political stability is one of the main factors influencing the association agreement leads us to conclude that EU enlargement was due in the beginning essentially to political reasons.

Geographic distance and the difference of level of income have a negative influence on the association decision as expected in literature.

In conclusion, the estimation of the quantitative impact of the association agreement on trade flows had a positive but moderated role which explains the political dimension of the association agreement on the first stage of Romania adhesion to EU. From an economic point of view the effect of regionalization on the trade of a transition country had a positive impact. From an econometric point of view the use of panel data methods with fixed effects is appropriate for obtaining unbiased and efficient parameter estimates.

Indeed, the association agreement to EU is endogenous and not exogenous and EU support policies have had a positive effect leading to an increase of Romanian exports towards the European market. Finally countries endogenously select to conclude an association agreement.

\section{REFERENCES}

1. Abrams, R.K. , International Trade Flows under Flexible Exchange Rates Federal Reserve Bank of Kansas City Economic Review 65, no. 3: 23-10., 1980

2. Aitken, The effect of the EEC and EFTA on European trade: a temporal cross-section analysis, American Economic Review, 63(5), 1973

3. Baier, L.S., Bergstrand, J.H, Do Free Trade Agreements Actually increase Members' International Trade?, FRB of Atlanta Working Paper No. 2005-3., 2005

4. $\quad$ Balassa B., European Economic Integration, North Holland, Oxford, 1975.

5. $\quad$ Baldwin R.E., Towards an Integrated Europe, London, CEPR, 1994.

6. $\quad$ Baltagi B.H., Econometric Analysis of Panel Data, John Wiley and Sons, Ltd., 2001

7. Bayoumi T., Eichengreen B., Is regionalism simply a diversion? Evidence from the evolution of the EC and EFTA, NBER Working Paper, 5283, 1995.

8. Bergstrand J.H., The Gravity Equation in International Trade: some Microeconomic Foundations and Empirical Evidence, The Review of Economics and Statistics, Vol. 67, No 3, August, pp. 474-481., 1985

9. Breuss F., Egger P., The Use and Misuse of Gravity Equations in European Integration Research, WIFO Working Paper, No. 97-03, 1997

10. Carrere C., Revisiting the Effects of Regional Trading Agreements on Trade Flows with Proper Specification of Gravity Model, European Economic Review vol. 50, 223-247, 2006

\footnotetext{
${ }^{14}$ Romania signed the association agreement in 1993 and ratified it in 1995.
} 
11. Cheng I.-H., Wall, H. Controlling for heterogeneity in gravity models of trade and integration, Federal Reserve Bank of Saint Louis Review 87, 49-63., 2005

12. Egger, P., and Pfaffermayr, M., Structural Funds, EU Enlargement, and the Redistribution of FDI in Europe, WIFO Working Papers, Nr. 195, 2003.

13. Eichengreen, B, and Irwin, D.A., Trade Blocks, Currency Blocks and the Disintegration of World Trade in the 1930s, Journal of International Economies vol 38, No 1,2 Février, pages 1-25.,1995

14. Evenett, S. J. and Keller, W, On Theories Explaining the Success of the Gravity Equation, Journal of Political Economy, University of Chicago Press, vol. 110(2), pages 281-316, 2002.

15. Fernandez R., Portes J., Returns to regionalism: an analysis of non traditional gains from regional trade agreements, World Bank Economic Review, 12(2), 197-220, 1998

16. Frankel, J., Regional trading blocs in the world economic system, Institute for International Economics, Washington, 1997

17. Frankel. J, Jeffrey A., Stein E., Wei S.J., Trading Blocs and Americas: The Natural, the Unnatural, and the Super-natural, Journal of Development Economics 47, no.1: 61-95., June 1995.

18. Ghosh S., Yamarik S., Are Regional Trading Arrangements Trade Creating?: An Aplication of Extreme Bounds Analysis, Journal of International Economics 63, no.2: 369-395., July 2004

19. Gujarati D. N., Basic Econometrics 4th ed., McGrawHill, 2003

20. Helpman, E. and Krugman, P., Market Structure and Foreign Trade. Increasing Returns, Imperfect Competition, and the International Economy, Cambridge MA/ London: MIT Pres. 1985.

21. Hsiao, Cheng, Analysis of Panel Data, Econometric Society Monography in quantitative economies No. 11, Cambridge University Press. , 1986

22. Krugman P.R., Geography and Trade, Published joint by Leuven University Press Leuven, Belgium and the MIT Press, Cambridge, Massachusetts, London, England, 1991

23. Krugman P.R., Venables A.J., Globalization and inequality of nations, Quarterly Journal of Economy, 110(4), 857-880, 1995

24. Mansfield, Edward, Helen Milner and B. Peter Rosendorff, Free to Trade: Democracies, Autocracies and International Trade Negotiations, American Political Science Review, 94(2): 305-322., 2000

25. Matyas, L., Proper Econometric Specification of the Gravity Model, The World Economie, 20 (3), 363-368, 1997

26. Melo, J de., Panagariya, A. \& Rodrik, D. The New Regionalism: A Country Perspective. In New Dimensions in Regional Integration, Melo, J. de \& Panagariya, A. eds., Cambridge, Cambridge University Press, 1993.

27. Sapir A., Winter C., Services Trade, Surveys in International Trade, edited by David Greenaway and L. Alan Winters, Oxford, UK: Blackwell, 1994.

28. Schiff M., Winters L.A., Dynamics and politics in regional integration arrangements: an introduction, The World Bank Economic Review, 12(2), pp.177 -95, 1998

29. Soloaga, I. and Winters, A.L., Regionalism in the nineties: what effect on trade?, The North American Journal of Economics and Finance, Elsevier, vol. 12(1), 1-29, 2001.

30. Torre, A., Kelly, M.R., Regional Trade Arrangements, International Monetary Fund Occasional Paper, 93, 1992.

31. Viner J., The Custom Union Issue, Carnegie Endowment for international peace, New York, 1950

32. Wooldrige, J.H., Econometric Analysis of Cross Section and Panel Data 2nd Edition: Books: The MIT Press Cambridge, Massachusetts London, England, 2002.

33. Wooldrige, J.H., Introductory Econometrics: A Modern Approach, 3rd Edition, Thomson South-Western, ISBN 0-324-28978-2.2005 